\title{
TO ASSESS NURSES' KNOWLEDGE OF UNIVERSAL PRECAUTIONS
}

\section{Neha Rehalia}

\section{Vivek Chaudhary*}

Pediatrician, Civil hospital Shahpur, Distt Kangra (HP)

Anaesthesiologist, Zonal hospital Dharamshala, Distt Kangra (HP)

${ }^{*}$ Corresponding author

ABSTRACT Introduction: This study aimed to assess the knowledge of health care workers (HCWs) towards universal precautions (UPs) Methodology: This study was undertaken between at Civil hospital, Shahpur. A selfadministered questionnaire assessing the knowledge and UPs was used. Results: Ten nurses were included in the study. All the nurses were females. $80 \%$ of them were aged above 30 years while $20 \%$ aged above 30 years. For $60 \%$ of them, length of services was above 3 years while for remaining it was less than 3 years. All of the nurses were HBV vaccinated. All the nurses had adequate knowledge of UPs. Conclusions: The HCWs had adequate knowledge and poor practice of UPs.

\section{KEYWORDS :}

\section{INTRODUCTION}

Health care workers (HCWs) are at risk of occupational hazards because they perform their clinical activities in hospitals. They are exposed to blood-borne infections from pathogens such as human immunodeficiency virus (HIV), hepatitis $B$ virus (HBV) and hepatitis $C$ virus (HCV), and from sharps injuries and contact with deep body fluids [1,2]. HCWs working in hospitals frequently provide care to patients whose $\mathrm{HIV}, \mathrm{HBV}$, and HCV statuses are unknown. Studies have shown that there is a $0.3 \%-0.5 \%$ occupational risk of infection with HIV after percutaneous exposure to HIV-contaminated blood [3], and the cumulative career risk may be as high as $1 \%-2 \%$ among emergency service staff or surgeons [4].

Universal precautions (UPs) are a set of precautions or actions designed to prevent HCWs from being exposed to blood and deep body fluids by applying the basic principles of infection control through hand washing, utilization of appropriate protective barriers such as gloves, masks, gowns, and eye shields, safe handling and disposal of needles, and safe decontamination of instruments and other contaminated equipment [5]. The term standard precautions is replacing universal precautions, as it expands the coverage of universal precautions by recognizing that anybody's fluid may contain contagious and harmful microorganisms [6].

This cross-sectional study aimed to assess nurses' knowledge of universal precautions.

\section{METHODS}

This study was conducted in civil hospital Shahpur. Subjects were nurses working in the hospital of the selected hospitals and had direct contact with patients.

A self-administered questionnaire was adapted. The questionnaire consisted of three parts. Part one was about respondent's personal information including age, sex, occupation, and length of service. Part two was about nurses' knowledge of UPs. In this section, respondents were asked to select the correct answer from 11 true or false statements, and a knowledge score was calculated for each respondent.

Data were presented as frequency or percentages.

\section{RESULTS}

\section{General characteristics}

Ten nurses were included in the study. All the nurses were females. $80 \%$ of them were aged above 30 years while $20 \%$ aged above 30 years. For $60 \%$ of them, length of services was above 3 years while for remaining it was less than 3 years. All of the nurses were HBV vaccinated.
Knowledge about universal precautions

In this study, all of nurses had correct knowledge of all the universal precautions.

\section{DISCUSSION}

In this study, all of nurses had correct knowledge of all the universal precautions. The results of the present study are slightly higher when compared to the study conducted by Lindy S van der Berg et al [4] in 2013(87\%). This showed that the knowledge of the participants towards application of universal precautions in all conditions is adequate.

Howevere, the present study was a self-reported survey and was conducted based on convenient sample with small sample size, which is confined to a limited area hence the results cannot be generalized. There is a need to conduct these types of studies on large sample with random sampling method.

\section{CONCLUSION}

Health care personnel, especially nurses have higher risk of getting occupational hazards. According to this study, the nurses have adequate knowledge in applying universal precautions.

Table 1: Knowledge about universal precautions

\begin{tabular}{|l|l|l|}
\hline & Questions (correct answers) & $\mathrm{n}(\%)$ \\
\hline 1 & $\begin{array}{l}\text { Universal precautions are applied to patients } \\
\text { with HIV and hepatitis only. (F) }\end{array}$ & $10(! 0 \%)$ \\
\hline 2 & $\begin{array}{l}\text { Isolation is necessary for patients with blood } \\
\text { borne infections. (F) }\end{array}$ & $10(! 0 \%)$ \\
\hline 3 & $\begin{array}{l}\text { Used needles can be recapped after giving an } \\
\text { injection. (F) }\end{array}$ & $10(! 0 \%)$ \\
\hline 4 & $\begin{array}{l}\text { For decontamination of devices (with only } \\
\text { contact with skin) washing with usual detergent } \\
\text { is enough. (T) }\end{array}$ & $10(! 0 \%)$ \\
\hline 5 & $\begin{array}{l}\text { Universal precautions are not necessary in } \\
\text { situations that might lead to contact with saliva. } \\
\text { (T) }\end{array}$ & $10(! 0 \%)$ \\
\hline 6 & $\begin{array}{l}\text { HCWs with non-intact skin should not be } \\
\text { involved in direct patient care until the } \\
\text { condition resolves. (T) }\end{array}$ & $10(! 0 \%)$ \\
\hline 7 & $\begin{array}{l}\text { Blood spills should be cleaned up promptly with } \\
\text { sodium hypochlorite. (T) }\end{array}$ & $10(! 0 \%)$ \\
\hline 8 & $\begin{array}{l}\text { Universal precautions should be applied to all } \\
\text { persons regardless of their infectious status. (T) }\end{array}$ & $10(! 0 \%)$ \\
\hline 9 & $\begin{array}{l}\text { Gloves are necessary in all caring procedures } \\
\text { for HIV patients. (F) }\end{array}$ & $10(! 0 \%)$ \\
\hline
\end{tabular}


\begin{tabular}{|l|l|l|}
\hline 10 & Universal precautions should apply to situations & $10(! 0 \%)$ \\
\hline
\end{tabular} that might lead to contact with tears. (F)

11 Universal precautions should apply to situations that might lead to contact with urine or feces. (F)

\section{REFERENCE}

1. Gerberding JL (1994) Incidence and prevalence of human immunodeficiency virus, hepatitis $B$ virus, hepatitis $C$ virus and cytomegalovirus amongst health care personnel at risk of blood exposure: final report from a longitudinal study. J Infect Dis 170: 1410-1417.

2. Reuben FL, Norden CW, Rockwell K, Hruska E (1983) Epidemiology of accidental needle- puncture wounds in hospital workers. Am J Med Sci 286: 26-30.

3. Chin J (2000) Control of communicable disease manual, 17th edition. Washington: American Public Health Association. 624 p.

4. Wears RL, Vukich DJ, Winton CN, Fluskey LL, MacMath TR, Li S (1991) An analysis of emergency physicians'

5. Center for Disease control and Prevention (1987) Recommendations for Prevention of HIV Transmission in Health-Care settings. MMWR suppl 36:001.

6. Sadoh WE, Fawole AO, Sadoh AE, Oladimeji AO, Sotiloye OS (2006) Practice of universal precautions among healthcare workers. J Natl Med Assoc 98: 722726.

7. Lindy S. van der Berg, Felicity M. Daniels. Do Nursing Students Know and Practice the Universal Precautions to Prevent Transmission of Infectious Agents? J Curationis,2013;36 (1): 